\title{
Are moths the missing pollinators in Subantarctic New Zealand?
}

\author{
Max N. Buxton ${ }^{1,2}$, Barbara J. Anderson ${ }^{3}$, Robert J.B. Hoare ${ }^{4}$ \& Janice M. Lord 1 \\ 'Department of Botany, University of Otago, Dunedin, New Zealand; \\ 2The New Zealand Institute for Plant and Food Research Limited, Ruakura, Hamilton, New Zealand; \\ ${ }^{3}$ The Otago Museum, Dunedin, New Zealand; \\ ${ }^{4}$ Manaaki Whenua - Landcare Research, Auckland, New Zealand
}

\begin{abstract}
On offshore islands, flowers are typically small, simple in colour and shape and more reliant on wind- or self-pollination than insect-mediated pollination. Islands also tend to have a species-poor pollinating fauna. The New Zealand Subantarctic islands (latitude between about $46^{\circ}$ and $60^{\circ}$ ) have a depauperate pollinator fauna. However, many flowers in this region are large, brightly coloured and apparently completely reliant on insect visitors for pollination. In the absence of bees and butterflies, moths and flies may be particularly important pollinators in the region. Using six Heath moth traps simultaneously over four nights in three different habitat types, 241 moths were caught, representing six species. We found that moths carried pollen identified to four plant species (Bulbinella rossii, Dracophyllum longifolium, Gentianella concinna and Acaena minor), with $B$. rossii and D. longifolium pollen being most abundant on moth bodies. Weather conditions explained moth abundance and distribution, but neither weather nor the number of moths caught were reliable predictors of their potential as pollinators; moths carried on average more pollen grains from more plant species in the shrubland despite harsh weather conditions and few individuals caught. Local flowering abundances may help explain this trend, with the predominance of $D$. longifolium flowering in the shrubland and B. rossii in the exposed megaherb field. This study is the first to provide evidence that moths may be capable of acting as pollinators in Subantarctic New Zealand, and that their contribution should not continue to be overlooked.
\end{abstract}

To access the supplementary material, please visit the article landing page

\section{Introduction}

Island systems are characteristically depauperate in pollinating fauna, with many groups either absent or under-represented (Lord 2015). The New Zealand Subantarctic islands conform to this pattern in that they have no bees or butterflies present; instead, flies and moths have been suggested as being important pollinators (Lloyd 1985; Bernardello et al. 2001; Lord et al. 2013; Lord 2015). Island plants tend to have a high representation of small, white or green, simple shaped flowers that are wind-pollinated (anemophilous) (Bernardello et al. 2001). Because the Subantarctic region is characteristically cold and windy, it is considered unsuited to flying insects, so wind- and self-pollination have typically been suggested as the main modes of pollination (Lord et al. 2013; Lord 2015). Nonetheless, the flowers of some Subantarctic plants have features that are highly indicative

\section{Keywords}

Pollination; islands; interactions;

Lepidoptera; ecology; mutualism

\section{Correspondence}

Max N. Buxton, The New Zealand Institute for Plant and Food Research Limited, Bisley Road, Ruakura, Hamilton 3214, New Zealand. E-mail max.buxton@plantandfood.co.nz

of insect pollination (entomophily), with some species being completely reliant on floral visitors for pollen transfer (Cheeseman 1919; Lord et al. 2013; Lord 2015).

The New Zealand Subantarctic islands comprise The Snares, Campbell Island, the Bounty Islands, The Antipodes and the Auckland Islands archipelago, of which Enderby Island $\left(50.4978^{\circ} \mathrm{S}, 166.2956^{\circ} \mathrm{E}\right.$; the focal island of this study) is a part. The Lepidoptera fauna of the Subantarctic islands currently consists of 89 species, of which $36(46 \%)$ are endemic to the region, with only four species $(11 \%)$ being endemic to more than one island (Patrick 1994). While the specific number of moth species present on Enderby Island is unknown, 47 have been recorded in the Auckland Islands, of which 44 are believed to be resident and 12 are endemic to the islands (Dugdale 1971; Patrick 1994). Of the resident species, 41 are capable of flight in at least the male sex (three species are flightless in both sexes). While various Diptera, 
Orthoptera and Coleoptera are present and potentially behave as pollinators in this region, their overall contribution as pollinators in this region is unknown.

The angiosperm flora of the New Zealand Subantarctic consists of 321 species across 51 families, of which 81 species $(25.2 \%)$ are endemic to the region, with $64.7 \%$ of these being single island occurrences (Lord 2015). While the specific number of plant species on Enderby Island is unknown, the Auckland Islands are reported to have 138 flowering species (Johnson \& Campbell 1975). Plants in this environment may employ a mixed-mating strategy that combines the advantage of outcrossing with the reproductive assurance of self-fertilization (Lord 2015). Given the history of this region and that conservation and restoration programmes cannot be successful without a detailed understanding of the reproductive biology of the plants, it is surprising that little is known about the pollination and reproductive strategies of plants in this region (Bernardello et al. 2001; Lord 2015).

Pollinating insects have been declining globally, which is of concern as declines in pollinating insects have been linked to a subsequent decline in the plants they pollinate (Thomas et al. 2004; Biesmeijer et al. 2006; Klein et al. 2007; Leather 2018). However, nocturnal interactions are often overlooked, presumably because of the difficulty of conducting surveys at night, leaving the role of moths as pollinators largely unknown (including day active moths) (MacGregor et al. 2014; Buxton et al. 2018). Documenting the previously undescribed relationships between Subantarctic moths and the plants they visit, and potentially pollinate, aids understanding of the importance of moths in these depauperate systems and also the level of complexity and diversity in these harsh environments (see MacGregor et al. [2014] and Buxton et al. [2018] for an overview of how moth-plant interactions are commonly assessed). Through systematic moth trapping and the use of pollen on moth bodies as a proxy for pollination, this study will address three key questions. (1) Is moth abundance and/or diversity influenced by habitat type? (2) Which pollen types are found most commonly on moths, and does this reflect local flowering species? (3) Does moth visitation appear to be more important in certain habitat types?

\section{Methods}

\section{Study site}

Enderby Island (700 ha) is the northernmost island in the Auckland Islands archipelago, located about $459 \mathrm{~km}$ south of Bluff, New Zealand (Wood et al. 2016; Supplementary Fig. S1). The vegetation on Enderby Island can be broken down into four main components: rātā (Metrosideros umbellata, Myrtaceae) forest, tussock grassland, shrubland and megaherb field. The windswept rātā forest dominates much of the southern and eastern sides of the island and has a diverse understorey, with Stilbocarpa polaris (Araliaceae) as the predominant flowering species. Once believed to occupy a large portion of the island, Poa litorosa (Poaceae) tussock grassland is present as a remnant on Enderby Island, more so on the coast of the southeastern side of the island (Taylor 1971). North and west of the rātā forest is largely Ozothamnus vauvilliersii (Asteraceae) shrubland, merging into Oreobolus (Cyperaceae) moor (Taylor 1971). The northern area of the island is predominantly megaherb field, dominated by dioecious Bulbinella rossii (Asphodelaceae). A detailed description of the vegetation of Enderby Island can be obtained from Taylor (1971).

\section{Systematic moth trapping}

On 2 and 3 December 2015, five Heath moth traps (light traps) were placed in the $B$. rossii-dominated megaherb field that covers most of the summit plateau of the island, with one additional trap placed in the more coastal, lower elevation rātā forest (locations 1-6, Table 1, Supplementary Fig. S1). Heath moth traps attract moths with an Actinic or ultraviolet light source above the trap box. The moths then get directed down a vane system, through

Table 1 Elevation and plant species in flower in the vicinity of each trapping location.

\begin{tabular}{lcll}
\hline Location & m a.s.I. & Exposure status & Putative biotically pollinated species flowering within 10 m of each trap \\
\hline 1 & 33 & Exposed & Bulbinella rossii (Asphodelaceae), Anisotome latifolia (Apiaceae), Epilobium brunnescens (Onagraceae) \\
2 & 35 & Exposed & Bulbinella rossii, Anisotome latifolia, Geranium microphyllum (Geraniaceae) \\
3 & 36 & Exposed & Bulbinella rossii, Anisotome latifolia, Gentianella concinna (Gentianaceae), Phyllachne clavigera (Stylidiaceae) \\
4 & 36 & Exposed & Bulbinella rossii, Anaphalioides bellidioides (Asteraceae), Phyllachne clavigera \\
5 & 36 & Exposed & Bulbinella rossii, Anaphalioides bellidioides, Phyllachne clavigera \\
6 & 12 & Sheltered & Stilbocarpa polaris, Veronica elliptica (Plantaginaceae), Bulbinella rossii, Acaena minor (Rosaceae) \\
7 & 28 & Intermediate & Dracophyllum longifolium var. cockayneanum (Ericaceae), Phyllachne clavigera, Acaena minor \\
8 & 21 & Intermediate & Dracophyllum longifolium var. cockayneanum, Phyllachne clavigera, Acaena minor \\
9 & 13 & Sheltered & Stilbocarpa polaris (Araliaceae) \\
\hline
\end{tabular}


a funnel and into the trap box. Trapping locations were selected based on their suitability for the placement of a trap while minimizing disturbance of the surrounding vegetation. One pitfall trap was dug into the ground on a flat surface clear of vegetation within $2 \mathrm{~m}$ of each trap, with the aim of trapping other non-flying insects, including flightless moths, which are known to occur on the island.

On 4 and 5 December 2015, moth trapping was conducted across three different habitat types. Two traps were kept in the highly exposed $B$. rossii-dominated megaherb field (locations 2, 3), two traps were relocated into an intermediate exposure zone dominated by Dracophyllum longifolium var. cockayneanum (Ericaceae, D. longifolium hereafter) (locations 7,8 ) and two traps were located in the sheltered rātā forest (location 6, 9) (Table 1, Supplementary Fig. S1). A quantitative measure of flowering abundances was not possible to achieve, but both the exposed and intermediate zones were noted as being abundant with flowers while the sheltered zone had considerably fewer flowers available. Between the hours of 23:00 and 01:00 on 4 and 5 December 2015, the megaherb field was searched for moths (away from the vicinity of the traps), and moths on flowers were collected into plastic tubes with these dimensions: $L 2.5 \mathrm{~cm} \times W 2.5$ $\mathrm{cm} \times H 6 \mathrm{~cm}$. The moon phase was centred around the third quarter, which occurred on 3 December 2015. Sunset was at 22:49:12 and sunrise was at 6:39:51, with traps being active between these times.

A Kestrel ${ }^{\mathrm{TM}} 4000$ or $\mathrm{Kestrel}^{\mathrm{TM}} 3000$ handheld weather station was attached to a stake above each moth trap to record microclimate data. The Kestrel was located ca. 30 $\mathrm{cm}$ above the lid of the trap, recording wind speed $(\mathrm{m} / \mathrm{s})$, temperature $\left({ }^{\circ} \mathrm{C}\right)$ and relative humidity (\%) at five-minute intervals. Flowering species within $10 \mathrm{~m}$ of each trap were recorded, and pollen voucher specimens were collected to aid in later identification of pollen removed from moth bodies. All moth traps were cleared daily, and moths euthanized in ammonia killing jars. A central body pin was placed through the thorax, each moth was given a unique label, and stored for transport. Moths were identified down to the lowest taxonomic level possible and are stored in the New Zealand Arthropod Collection in Auckland.

\section{Preliminary pollen transfer experiment}

A preliminary study to determine if moths are able to transfer pollen between flowers was conducted. Pollen tracker (ultraviolet fluorescent paint particles) was placed on the anthers of a male $B$. rossii with a paint brush, and placed inside a sealed container alongside a female $B$. rossii flower. One Graphania erebia individual was then placed in the container and left overnight. The following morning the moth was euthanized in an ammonia killing jar and both the female flower and the moth were examined for pollen tracker with the use of an ultraviolet torch.

\section{Pollen analysis}

Moths were swabbed for pollen with ca. $3 \mathrm{~mm} \times 3 \mathrm{~mm}$ $\times 3 \mathrm{~mm}$ cubes of Fuchsin jelly on entomological body pins. Each moth was uniformly swabbed-the antennae were rubbed down with the cube, the moth was swabbed thrice on the face (once on each eye and once more on the proboscis), twice on the thorax (one on each side of the central body pin) and twice down the abdomen. Each cube was placed on a labelled microscope slide, melted on a slide warmer and then a cover slip was placed on top. Pollen grains were located under $100 \times$ magnification and if present, identified under $400 \times$ magnification by referring to the reference pollen slides (Supplementary Fig. S2). The total number of pollen grains per plant species was recorded for each moth.

\section{Data analysis}

A Poisson probability distribution generalized linear model was constructed using a log link function to examine the effect of date, location and the interaction between date and location on the number of individuals at each trapping location. Akaike's Information Criterion was used to compare the goodness of the fit of models, and type III Wald's chi-squared tests were used to test the significance of terms. Chi-square tests for heterogeneity were performed to test the effect of location on the total number of pollen grains on moths caught on 4 and 5 December 2015.

All figures were constructed in R version 3.5.1 (201807-02) (R Core Team 2018), and statistics were performed in IBM SPSS Statistics (version 24) 2016 and Statistix Analytical Software (version 9).

\section{Results}

\section{Moth abundance and diversity}

A total of 241 moths were caught, encompassing six species. Graphania erebia (Noctuidae) was the most abundant species, with 231 individuals caught (Fig. 1). All other species were less abundant: Epiphryne charidema (Geometridae) (three individuals), Heterocrossa philpotti (Carposinidae), Pyrgotis plagiatana (Tortricidae) and Scoparia triscelis (Crambidae) (two individuals of each species), and Eudonia aff. psammitis (Crambidae) (one individual).

Trapping locations for 2 and 3 December 2015 were focused on the megaherb field (Table 1) with one location 


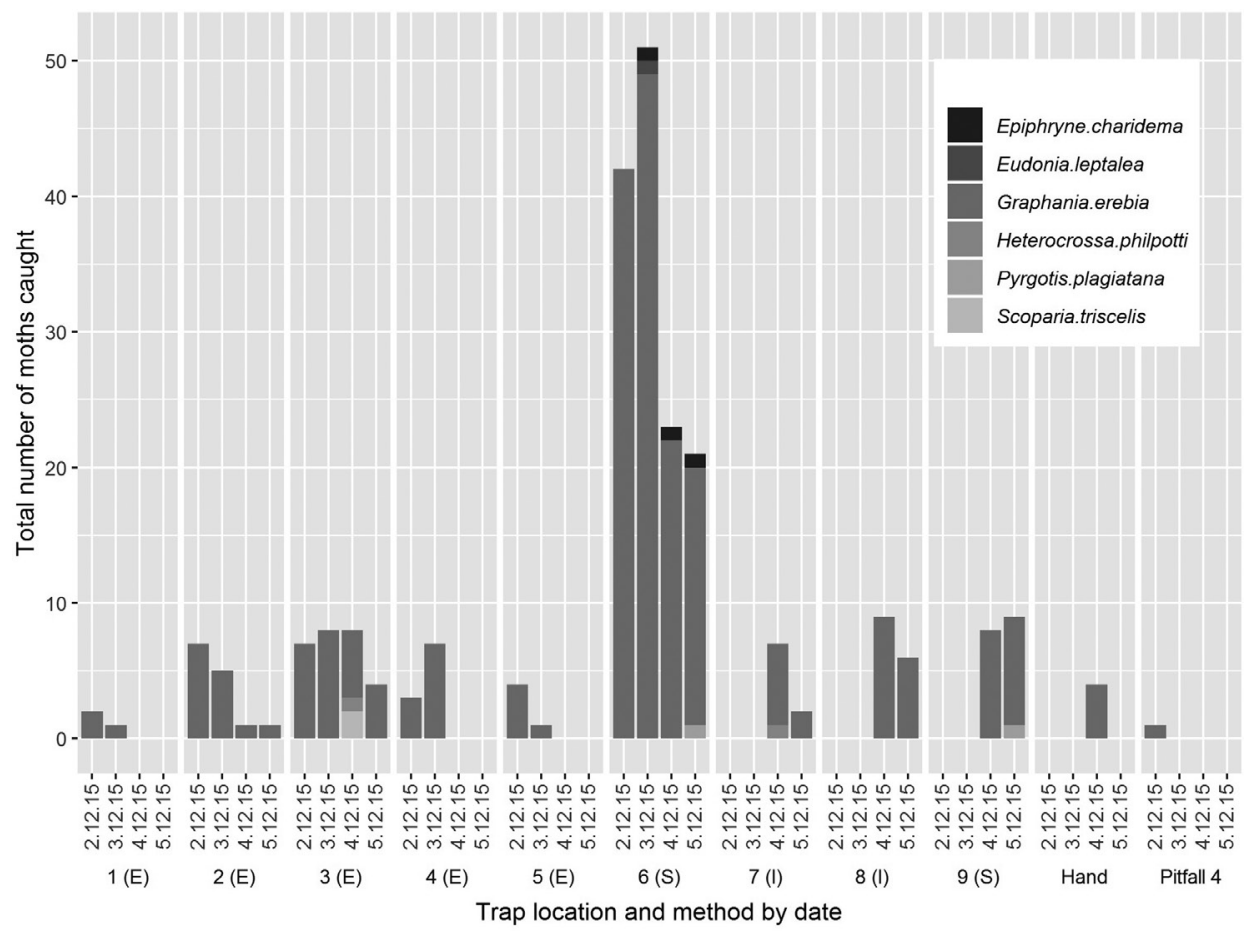

Fig. 1 Total abundances of the six moth species caught at nine locations on Enderby Island over a four-night period. "Pitfall 4" refers to the moth that was caught in the pitfall trap at location 4. "Hand" refers to the moths caught by hand. Letters beside the trap locations indicate the exposure gradient: sheltered (S), intermediate (I) and exposed (E).

in the rātā forest. On both of these nights, the rātā forest had the highest moth abundance (Fig. 1). The pitfall trap at location 4 was the only successful pitfall trap, capturing one winged G. erebia individual.

Trapping locations for 4 and 5 December 2015 were located along an exposure gradient-from the northernmost exposed megaherb field, through the intermediate shrubland, to the sheltered rātā forest towards the south coast of the island. On these nights, most moths were caught in the sheltered forest $(n=61)$, followed by the intermediate shrubland zone $(n=24)$ and lastly the exposed megaherb field zone $(n=14)$ (Fig. 1). On 4 December 2015, four moths were also caught by hand, three of which were removed from B. rossii flowers in the lower margin of the megaherb field. An additional moth was caught that same night in the rātā forest, ca. $50 \mathrm{~m}$ from location 9.

Overall, there was a significant effect of both date $(p=0.008$, Wald chi-square $=11.715, \mathrm{df}=3)$ and location $(p \leq 0.001$, Wald chi-square $=183.875, \mathrm{df}=10)$ on the number of moth individuals caught, but the interaction between date and location was not significant $(p=0.530$, Wald chi-square $=10.99, \mathrm{df}=12$ ).

On 2 December 2015, only G. erebia individuals were caught at all trapping locations. On 3 December 2015 , location 6 had the greatest species diversity, with three species caught (Fig. 1). On 4 December, location 3 had the greatest species diversity with three species caught, while on 5 December location 6 again had the greatest species diversity with three species caught. The highly unbalanced species evenness prevents us from definitive conclusions from these data. However, trapping at location 6 yielded the greatest degree of moth diversity in total, with four of the six moth species being trapped there overall. While temperature averages were consistent between trapping locations, the average wind speeds were greater in the exposed and intermediate locations and lower in the sheltered locations (Fig. 2).

\section{Pollen abundance and diversity}

All 241 moths caught were swabbed for pollen. Nineteen G. erebia individuals carried pollen belonging to four plant species: B. rossii (Asphodelaceae), D. longifolium (Ericaceae), G. concinna (Gentianaceae) and A. minor (Rosaceae) (Fig. 3). Dracophyllum longifolium pollen was the most abundant, with a total of 319 grains removed from nine moth individuals. Bulbinella rossii pollen was the second most abundant, with 236 grains removed from 10 moths. The largest amount of $B$. rossii pollen was removed from 

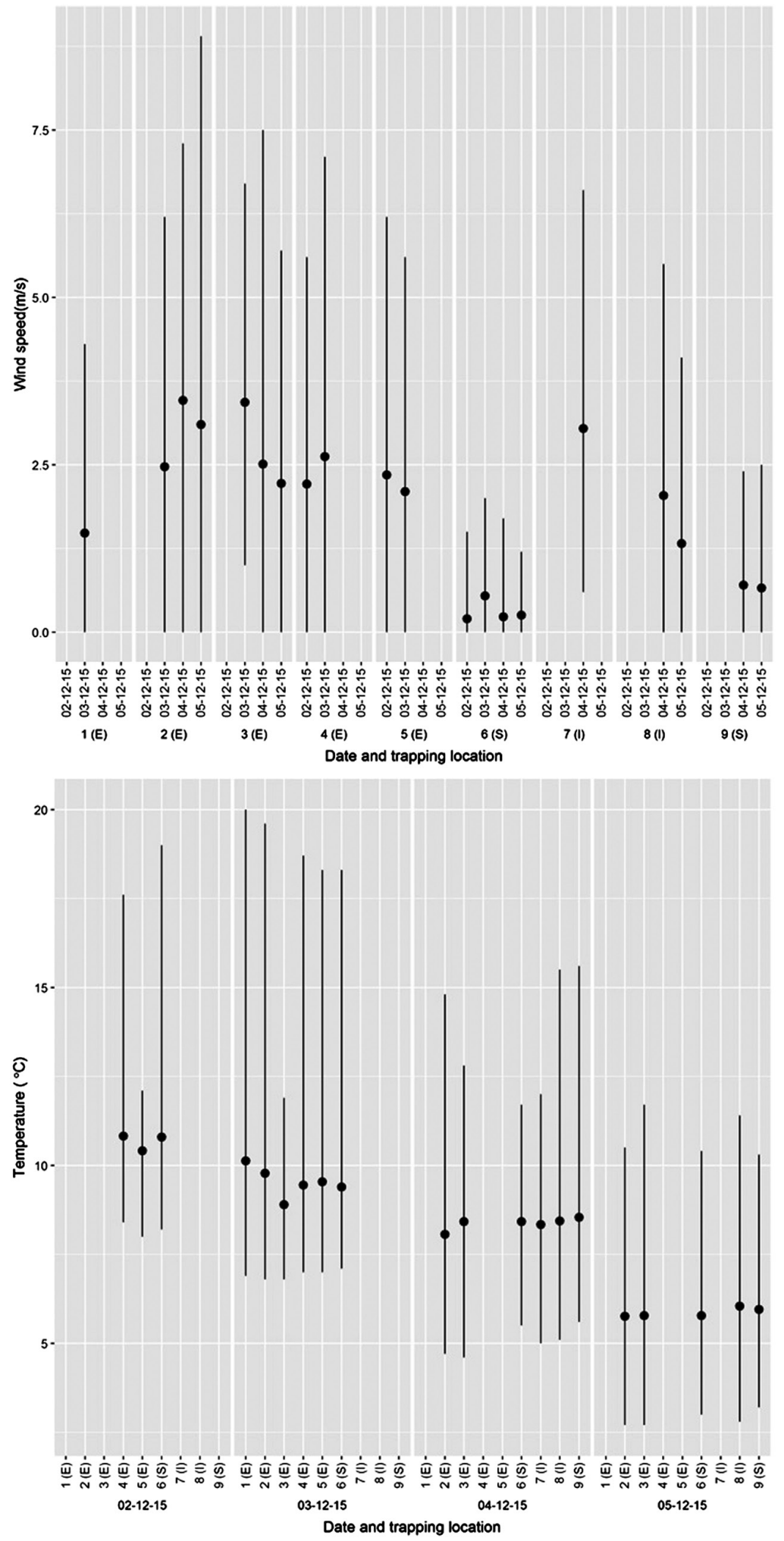

Fig. 2 Maximum, minimum and average wind speed $(\mathrm{m} / \mathrm{s})$, and temperature $\left({ }^{\circ} \mathrm{C}\right)$ values for the trapping locations on Enderby Island, 2-5 December 2015. Values are based on the weather data recorded for a 24-hour period beginning at 12:00 on each day. Letters beside the trap locations indicate the exposure gradient: sheltered (S), intermediate (I) and exposed (E). 


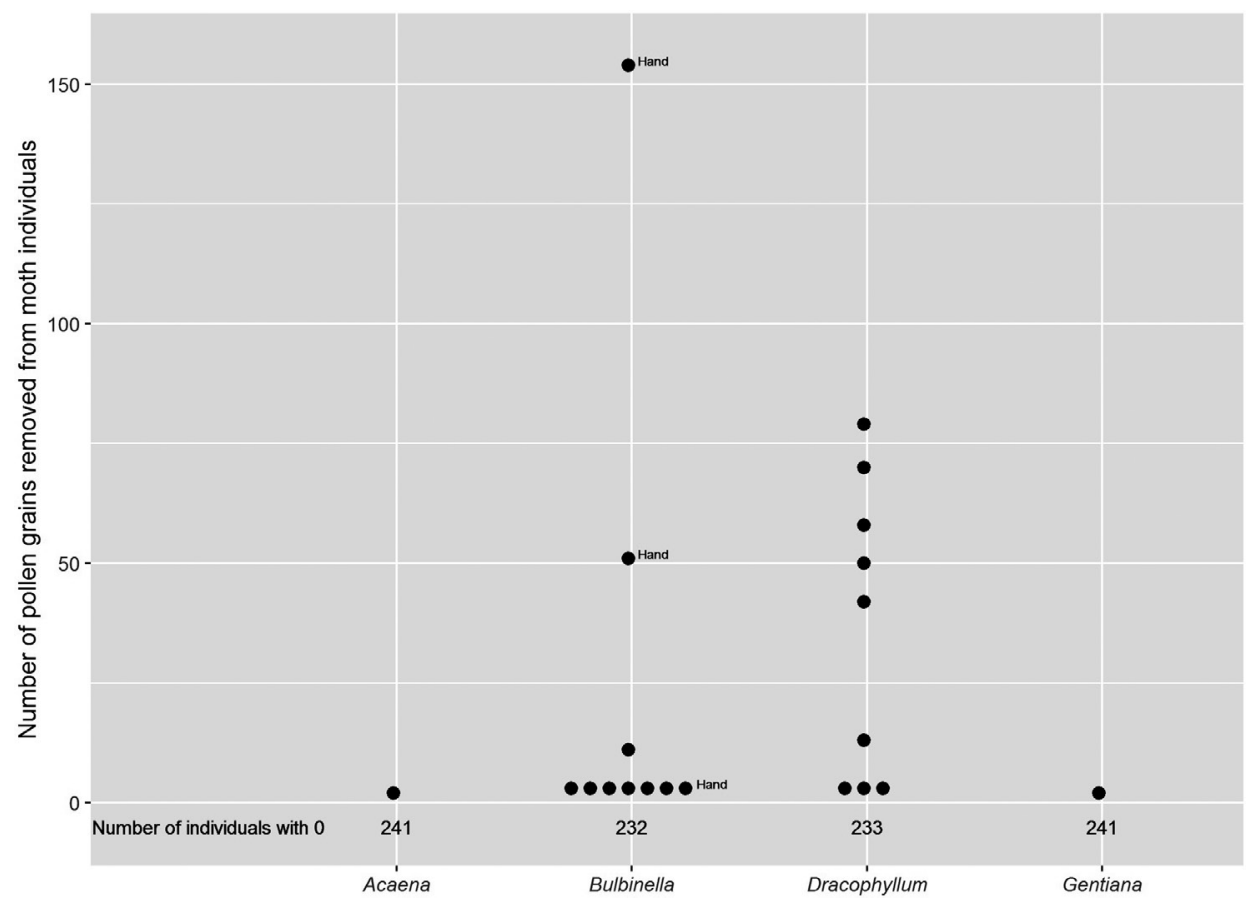

Fig. 3 Variation in the number of pollen grains removed from individual moths. "Hand" in the Bulbinella column denotes the number of pollen grains on moths caught by hand.

Table 2 Total distribution and abundance of pollen grains removed from moths caught on Enderby Island over a four-night period. Traps and locations where moths did not carry pollen have been excluded from the table.

\begin{tabular}{llcccc}
\hline Date & Location & Bulbinella & Dracophyllum & Acaena & Gentiana \\
\hline 3.12 .15 & 2 (Exposed) & 12 & - & - & - \\
4.12 .15 & 7 (Intermediate) & - & 114 & 2 & - \\
4.12 .15 & 8 (Intermediate) & - & 13 & - & - \\
4.12 .15 & 6 (Sheltered) & 8 & - & - & - \\
4.12 .15 & Hand & 210 & - & - & - \\
5.12 .15 & 3 (Exposed) & 4 & 137 & - & - \\
5.12 .15 & 7 (Intermediate) & 1 & 55 & - & - \\
5.12 .15 & 8 (Intermediate) & 1 & & - \\
\hline
\end{tabular}

a Pollen grains removed from moths caught by hand.

moths caught by hand on male $B$. rossii flowers, with fewer pollen grains being removed from moths caught in traps (Fig. 3). Two grains of A. minor were present on one moth. Two grains of $G$. concinna were also present on one moth. Only two moth individuals were found to carry more than one pollen species; one with $B$. rossii and $D$. longifolium (1 and 58 grains, respectively) and the other with $B$. rossii and G. concinna (one and two grains, respectively). Overall, G. erebia showed a strong association with two plant species (B. rossii and D. longifolium) and a weak association with two species (G. concinna and A. minor).

There was an overall significant effect of trapping location on the number of pollen grains on moth bodies on 4 and 5 December (chi-square $=28.85, p=0.00, \mathrm{df}=3$ )
(Table 2). Because of low sample sizes and a predominance of zero values, analysis was not conducted for 2 or 3 December for differences among pollen species.

A total of 559 pollen grains were removed from moth bodies across all locations and nights. Eight were removed from two moths in the sheltered zone, 325 were from 11 moths in the intermediate zone and 226 were from six moth individuals in the exposed zone (Table 3 ). Of the 226 pollen grains removed from the exposed zone, 210 were removed from the three moths caught by hand (Fig. 3). Of the moths that carried pollen, moths caught in traps in the exposed zone carried on average 5.3 pollen grains, moths in the intermediate zone carried on average 29.5 pollen grains and moths in 
Table 3 The likely importance of moths as pollinators for each habitat type, using the proportion of moths that carried pollen and the average number of pollen grains carried as a proxy for pollination. Hand-caught moths have been excluded because of different collection method.

\begin{tabular}{lccc} 
Exposure gradient & Proportion of moths carrying pollen & Average number of pollen grains carried & Total number of pollen grains carried \\
\hline Exposed & 21.43 & 5.33 & $226(40.43 \%)$ \\
Intermediate & 47.83 & 29.55 & $325(58.14 \%)$ \\
Sheltered & 3.28 & 4 & $8(1.43 \%)$ \\
\hline
\end{tabular}

the sheltered zone carried on average four pollen grains (Table 3).

There was no correlation between the total number of pollen grains on moth bodies and the number of moth individuals caught at each location.

\section{Preliminary pollen tracker experiment}

Graphania erebia was capable of transferring pollen tracker between male and female B. rossii flowers (Supplementary Fig. S3). The individual moth transferred 42 pollen tracker grains to the female flower with two tracker grains remaining on the moth body (one on the thorax and one on the head).

\section{Discussion}

\section{Pollen on moth bodies and the potential for pollination}

This study provides the first evidence that moths can pollinate plants in the New Zealand Subantarctic region. Our observations indicated that moths may be able to deliver pollination services even in extreme conditions typically unsuited for flying insects, with wind speeds reaching up to $6.6 \mathrm{~m} / \mathrm{s}$ and temperatures as low as $2.7^{\circ} \mathrm{C}$. In particular, species with very dense scales like those in Noctuidae (which make up the large majority of specimens recorded) may be better able to withstand the cool temperatures recorded (Sutrisno 2008). Environmental conditions did not explain the distribution of pollen grains on moth bodies as more pollen grains were removed from moths caught in the intermediate zone despite environmental conditions there being more severe than in the sheltered forest.

Graphania erebia (Noctuidae) was the most common species caught and is a highly variable species endemic to the Auckland Islands. Pleurophyllum, Carex, Urtica, Stilbocarpa and Olearia are known larval food plants (Patrick 1990, 1994). Graphania erebia was present in every trapping location on each night and was observed crawling on $B$. rossii flowers and moving down to the base of the plant, making visible contact with the anthers in the process (Fig. 4). This non-flying behaviour could explain

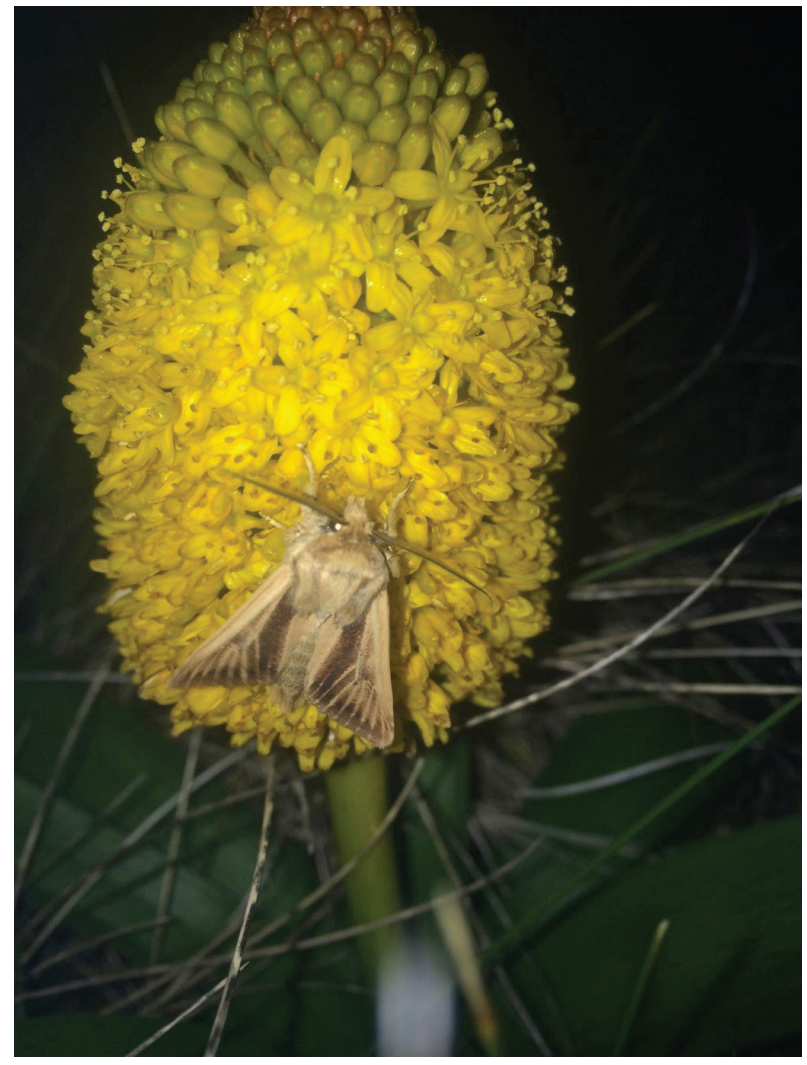

Fig. 4 Graphania erebia foraging on a male Bulbinella rossii.

how this species copes with strong winds and also why G. erebia was caught in the pitfall trap. Individuals were also observed to remain motionless during strong bursts of wind but were actively flying and crawling during breaks in the wind. Graphania erebia was the only species observed to interact with plants, in particular, B. rossii and $D$. longifolium. In contrast, the relationship between $G$. erebia and the plants $G$. concinna and $A$. minor was weak. Whether this is a reflection of the lower flowering abundance of G. concinna and A. minor or because G. erebia moths infrequently visit these two plant species remains unknown. Graphania erebia may be crucial for pollination of Subantarctic D. longifolium as other flower visitors are unknown. The highest abundance and diversity of pollen grains were also found on G. erebia individuals caught 
in D. longifolium shrubland despite fewer moths being caught there than in other zones.

The floral characteristics of $D$. longifolium align with what is known as the moth pollination syndrome, which involves plants having pale, tubular flowers offering nectar rewards and that are strongly scented at night (Proctor et al. 1996; Buxton et al. 2018). The inflorescence of D. longifolium is a 6- to 15 -flowered raceme $4-5 \mathrm{~cm}$ long. The flowers have white tubular corolla 4-5 $\mathrm{mm}$ long and 2.5-3.5 mm wide, are cylindrical in shape and widen at the mouth (Allan 1961; New Zealand Plant Conservation Network 2014). How well floral syndromes-which match flower characteristics to certain guilds of visitors (Newstrom \& Robertson 2005)-allow us to accurately predict pollinators has recently come under some scrutiny; flowers that are visited by moths can still be visited by other functional groups, increasing their overall fitness (see Ollerton et al. [2009] and Rosas-Guerrero et al. [2014] for discussions on the usefulness of floral syndromes).

Graphania erebia may also be an important pollinator for $B$. rossii. Bulbinella rossii pollen was the only pollen removed from G. erebia individuals caught in the exposed megaherb field and in the sheltered rātā forest. Bulbinella rossii dominated the megaherb field, but there were very few individuals near the edge of the rātā forest, suggesting that $G$. erebia moths either actively seek out B. rossii or are capable of travelling long distances at night. However, B. rossii does not fit the "moth floral syndrome": the inflorescence is a cylindrical raceme up to $150 \times 600 \mathrm{~mm}$, with numerous densely crowded yellow flowers 10-14 $\mathrm{mm}$ in diameter, the tepals outnumbering the sepals and the anthers copiously full of pollen (Moore \& Edgar 1970; New Zealand Plant Conservation Network 2014). Bulbinella rossii is instead "open-access," being visited by a range of invertebrates (Lepidoptera, Diptera, Coleoptera, Orthoptera) that likely vary in their role as pollinators (if pollination occurs at all) (Lord et al. 2013; M. Buxton, pers. obs.). Even so, G. erebia (and other moth species) may be more important than Diptera as pollinators of $B$. rossii because of these moths' greater surface area and more active foraging. In our study, G. erebia was observed to crawl over B. rossii inflorescences, closely contacting anthers (Fig. 4), while diurnal foraging Melangyna novaezelandiae (Diptera: Syrphidae) were largely motionless while consuming the pollen from the anthers. However, visitation rates have been identified as being more important than other foraging behaviour (such as the duration of a visit) when measuring pollinator effectiveness (Ne'eman et al. 2010). As this type of data is not available for $B$. rossii, no inferences on pollinator effectiveness can be made at this stage. Likewise, while the presence of pollen on moth bodies is indicative of a potentially mutualistic interaction, alone it is not conclusive evidence of pollination taking place.

In a preliminary captive study, G. erebia was capable of transferring pollen tracker between male and female B. rossii flower (Supplementary Fig. S3), indicating $G$. erebia (and other moth species) could act as pollinators to some capacity. However, to determine the relative importance of moths as pollinators for various plant species, pollen loads on other floral visitors need to also be documented and controlled pollinator exclusion experiments conducted (e.g., Lord et al. 2013).

When pollen grains on moth bodies serve as a proxy for pollination, collection method may play a role in interpreting the importance of the floral visitor. Three $G$. erebia individuals were directly removed from $B$. rossii flowers into specimen jars and contained both high and low numbers of pollen compared with the moths caught in traps. Whether additional pollen was accidentally removed from flowers is uncertain, but regardless there do appear to be some discrepancies between the two collection methods.

None of the other moth species caught was carrying pollen grains at the time of our study. Epiphryne charidema (Geometridae) was the second most abundant moth species $(n=3)$ and uses Dracophyllum as a larval food plant (Patrick 1990, 1994). Eudonia leptalea (Crambidae) is a close relative of E. psammitis and these species are poorly differentiated, leading to the individual caught in this study being identified as E. aff. psammitis (R. Hoare, pers. obs.). Larval food plants for E. leptalea and E. psammitis are mosses and Colobanthus. Pyrgotis plagiatana (Tortricidae) $(n=2)$ is present in the Auckland Islands and on Campbell Island, as well as throughout mainland New Zealand. Larval food plants for this species include Pleurophyllum, Coprosma, Veronica, Ozothamnus, Myrsine and Acaena (Dugdale 1971; Patrick 1990, 1994). All of these moth species were caught in the rātā forest, but the plants that adult moths interact with remain unknown. Heterocrossa philpotti (Carposinidae) $(n=2)$ is endemic (at least at subspecies level) to the Auckland Islands, and although Myrsine has been proposed, there is no known food plant for larvae (Dugdale 1971; Patrick 1994). Scoparia triscelis (Crambidae) $(n=2)$ is found in the Auckland Islands and on Campbell Island, as well as on the North and South islands of New Zealand. There are no known food plants for the larvae of this species (Patrick 1990, 1994). One $H$. philpotti was caught in the megaherb field, and one $H$. philpotti and both $S$. triscelis were caught in the intermediate zone. Both of these areas were highly diverse in vegetation and flowers were abundant, yet no pollen was removed from either of these species. As interactions between these moths (and larvae) with plants remain unknown, further investigation is required. 
Moths probably interact with additional plant species not identified in this survey, and as such these findings are likely to be an under-representation of moth-plant interactions in this region. The low sampling intensity a short time period may have missed some plant-moth relationships. Pollen from only four of the 10 flowering species recorded near the traps was found on moths. Moths are known to visit the flowers of various Veronica spp. (Thomson 1928) and while Veronica elliptica had begun flowering on Enderby Island at the time of this study the flowers were few-whether no relationship was found because the moths do not visit these flowers, the short sampling period or the low flowering abundance remains unknown. An unidentified moth has also previously been observed visiting $O$. vauvilliersii (M. Buxton, pers. obs.), but during this study the species was yet to flower. Inclusion of $V$. elliptica and $O$. vauvilliersii (and other plant species) and sampling over a greater length of time in future studies in this region are warranted. Moths do not appear to pollinate plants such as $S$. polaris and Anisotome latifolia. Instead various Diptera and Coleoptera have been observed visiting the flowers of these species (Lord et al. 2013).

A pollinator's importance is dependent not only on its efficiency in transferring a large amount of pollen but also on the abundance and visiting rate of the pollinator (Herrara 1987; Newstrom \& Robertson 2005). Pollinator efficiency can be measured and inferred in many ways; this study used the average number of pollen grains as well as the proportion of moths found to carry pollen as a proxy for quality of pollination service (see Buxton et al. [2018] and MacGregor et al. [2014] for reviews of the way pollination via moths is measured globally). Both approaches used in this study indicate that the potential role of moths as pollinators may be most important in the intermediate shrubland zone and least important in the sheltered rātā forest. However, this could be highly dependent on which species were flowering at the time of the study; D. longifolium was flowering heavily in the intermediate zone and showed the strongest relationship with moths. As our study took place over a short period of time, additional moth-plant relationships may remain to be discovered. If additional relationships are discovered with plants not in flower at this time of the study, moths may be important pollinators in other areas of the island.

\section{Moth abundance and distribution}

Prevailing wind speed and temperature have been shown to influence moth activity (McGeachie 1989), although the specific wind speeds at which moths have been caught are not readily available in the literature. While there was considerable variation in average temperatures between nights, differences between trapping locations on any given night do not explain moth distribution patterns. However, average wind speeds were substantially lower in the sheltered zones, where moth abundance was highest, and may therefore be the driving factor behind the distribution patterns observed. High wind speeds could blow individuals off islands into the sea, but also individuals may be blown away from their preferred habitats within an island (Medeiros \& Gillespie 2011). As such, moth distribution may not be directly influenced by the presence or absence of plants moths interact with, as was predicted, but may be an artefact of the buffering effect that the rātā forest provides against wind.

Graphania erebia constituted $95.8 \%$ of moths caught and as such little inference can be made regarding changes in moth diversity across the trapping locations; however, locations 6 (rātā forest) and 3 (megaherb field) showed the highest diversity $(n=3)$. This is partially consistent with observations made by Patrick (1990), who states that the diversity decreases dramatically further from the coast. Graphania erebia dominating the moth fauna caught is likely due to the better ability of Noctuidae species to fly in wet and windy conditions compared to other families, such as Geometridae (M. Buxton, pers. obs.). Three noctuid species have been recorded from the Auckland Islands, but only G. erebia is known to be resident so this dominance is to be expected. However, the overall low species diversity recorded is potentially concerning, but this difference could be an artefact of different collection methods and locations. Despite the marked seasonality of the moth community (Patrick 1990, 1994), the very low diversity observed during this study suggests that a thorough reassessment of the moth community in Subantarctic New Zealand is warranted.

\section{Conclusions}

Despite harsh environmental conditions unsuited to flying insects, moths have the potential to behave as pollinators in New Zealand Subantarctic islands. Because collection in this study was restricted to a four-day period, the relationships identified in this study are likely to be an under-representation of the true role of moths as potential pollinators. The moths recorded are likely generalist in behaviour, visiting the most abundant flowers in an area. Generalist species are often less vulnerable to perturbation than specialists (Potts et al. 2010). However, because of the depauperate pollinating fauna on Enderby Island, a loss of generalist moths may have catastrophic effects on the plant community as a whole (Archibald et al. 1986; Patrick 1990; Potts et al. 2010). In the Subantarctic, the relationship between moths and plants may be exceptionally critical on account of the lack of bees and butterflies; 
however, the role of other pollinating fauna, like Diptera, should not be overlooked. While the results of this study do not serve as definitive evidence of pollination, they should be considered as indicators of mutualistic relationships. This work provides a basis for future studies, incorporating additional plant and moth species to gain a better understanding of the extent of moths as pollinators. To get a clearer picture of the role of moths as pollinators, their contribution to pollination needs to be compared with other pollinating taxa and followed through to seed set.

\section{Acknowledgements}

The authors would like to acknowledge the University of Otago, Department of Botany and Ruakura Research Centre at the New Zealand Institute for Plant and Food Research Limited for the use of facilities during this research. They would like to thank Captain Henk Haazen and the crew of the Tiama for providing passage to Enderby Island, and for feeding them amazing food they mostly kept down. They would also like to thank Kate Richards for her help in producing the figures, as well as anonymous reviewers for their time reviewing this manuscript. The Department of Conservation Subantarctic/Quarantine Team, Murihiku Office, provided logistical and quarantine support. This research was conducted under the Department of Conservation permit number 47966-FAU.

\section{Disclosure statement}

The authors report no conflict of interest.

\section{Funding}

Transport was partially funded by a grant from the National Geographic Society (grant no. 9791-15) and a Peter Bannister Student Field Grant, with the Royal Forest and Bird Protection Society (Dunedin Branch) providing funding for moth traps. Additional funding for this study was provided by the Royal Society of New Zealand through a Rutherford Discovery Fellowship (12-LCR-001) to BJA.

\section{References}

Allan H.H. 1961. Flora of New Zealand. Vol. I. Wellington, New Zealand: Government Printer.

Archibald R.D., Heads M.J., Patrick B.H. \& Tangney R.S. 1986. The Lepidoptera, bryophytes and panbiogeography of the Auckland Islands. Dunedin, New Zealand: Otago Entomological Society.

Bernardello G., Anderson G.J., Stuessy T.F. \& Crawford D.J. 2001. A survey of floral traits, breeding systems, floral visitors, and pollination systems of the angiosperms of the Juan Fernández Islands (Chile). The Botanical Review 67, 255-308, doi: 10.1007/BF02858097.

Biesmeijer J.C., Roberts S.P.M., Reemer M., Ohlemuller R., Edwards M., Peeters T., Schaffers A.P., Potts S.G., Kleukers R., Thomas C.D., Settele J. \& Kunin W.E. 2006. Parallel declines in pollinators and insect-pollinated plants in Britain and the Netherlands. Science 313, 351-353, doi: 10.1126/science.1127863.

Buxton M.N., Anderson B.J. \& Lord J.M. 2018. The secret service-analysis of the available knowledge on moths as pollinators in New Zealand. New Zealand Journal of Ecology 42, 1-9, doi: 10.20417/nzjecol.42.11.

Cheeseman T.F. 1919. The vascular flora of Macquarie Island. Australasian Antarctic Expedition 1911-1914. Scientific reports. Series C. Zoology and botany. Vol. 7. Part 3. Sydney: Government Printing Office.

Dugdale J.S. 1971. Entomology of the Auckland Islands and other islands south of New Zealand: Lepidoptera, excluding non-Crambine Pyralidae. Pacific Insects Monograph 27, 55-172.

Herrara C.M. 1987. Components of pollinator "quality": comparative analysis of a diverse insect assemblage. Oikos 50, 79-90, doi: 10.2307/3565403.

Johnson P.N. \& Campbell D.J. 1975. Vascular plants of the Auckland Islands. New Zealand Journal of Botany 13, 665-720, doi: 10.1080/0028825X.1975.10430354.

Klein A.M., Vaissière B.E., Cane J.H., Steffan-Dewenter I., Cunningham S.A., Kremen C. \& Tscharntke T. 2007. Importance of pollinators in changing landscapes for world crops. Proceedings of the Royal Society: Biological Sciences 274, 303-313, doi: 10.1098/rspb.2006.3721.

Leather S.R. 2018. "Ecological Armageddon"-more evidence for the drastic decline in insect numbers. Annals of Applied Biology 172, 1-3, doi: 10.1111/aab.12410.

Lloyd D.G. 1985. Progress in understanding the natural history of New Zealand plants. New Zealand Journal of Botany 23, 707-722, doi: 10.1080/0028825X. 1985.10434239.

Lord J.M. 2015. Patterns in floral traits and plant breeding systems in Southern Ocean Islands. AoB Plants 7, article no. plv095, doi: 10.1093/aobpla/plv095.

Lord J.M., Huggins L., Little L.M. \& Tomlinson V.R. 2013. Floral biology and flower visitors on Subantarctic Campbell Island. New Zealand Journal of Botany 51, 168-180, doi: 10.1080/0028825X.2013.801867.

MacGregor C.J., Pocock M.J.O., Fox R. \& Evans D.M. 2014. Pollination by nocturnal Lepidoptera, and the effects of light pollution: a review. Ecological Entomology 40, 187-198, doi: 10.1111/een.12174.

McGeachie W.J. 1989. The effect of moonlight illuminance, temperature and wind speed on light-trap catches of moths. Bulletin of Entomological Research 79, 185-192, doi: 10.1017/S0007485300018162.

Medeiros M.J. \& Gillespie R.G. 2011. Biogeography and the evolution of flightlessness in a radiation of Hawaiian moths (Xyloryctidae: Thyrocopa). Journal of Biogeography 38, 101-111, doi: 10.1111/j.1365-2699. $2010.02402 . x$. 
Moore L.B. \& Edgar E 1970. Flora of New Zealand. Vol. II. Wellington, New Zealand: Government Printer.

Ne'eman G., Jürgens A., Newstrom-Lloyd L., Potts S.G. \& Dafni A. 2010. A framework for comparing pollinator performance: effectiveness and efficiency. Biological Reviews 85, 435-451, doi: 10.1111/j.1469-185X.2009.00108.x.

Newstrom L. \& Robertson A. 2005. Progress in understanding pollination systems in New Zealand. New Zealand Journal of Botany 43, 1-59, doi: 10.1080/0028825X.2005.9512943.

New Zealand Plant Conservation Network (NZPCN) 2014. Dracophyllum cockayneanum. Accessed on the internet at http://www.nzpcn.org.nz/flora_details.aspx? $\mathrm{ID}=2320$ on 24 July 2016.

Ollerton J., Alarcon R., Waser N.M., Price M.V., Watts S., Cranmer L., Hingston A., Peter C.I. \& Rotenberry J. 2009. A global test of the pollination syndrome hypothesis. Annals of Botany 103, 1471-1480, doi: 10.1093/aob/ mcp031.

Patrick B.H. 1990. Lepidoptera of the Auckland Islands. Dunedin, New Zealand: Department of Conservation.

Patrick B.H. 1994. Antipodes Island Lepidoptera. Journal of the Royal Society of New Zealand 24, 91-116, doi: 10.1080/03014223.1994.9517457.

Potts S.G., Biesmeijer J.C., Kremen C., Neumann P., Schweiger O. \& Kunin W.E. 2010. Global pollinator declines: trends, impacts and drivers. Trends in Ecology and Evolution 25, 345-353, doi: 10.1016/j.tree.2010.01.007.
Proctor M., Yeo P. \& Lack A. 1996. The natural history of pollination. London: HarperCollins.

Rosas-Guerrero V., Aguilar R., Marten-Rodriguez S., Ashworth L., Lopezaraiza-Mikel M., Bastida J.M. \& Quesada M. 2014. A quantitative review of pollination syndromes: do floral traits predict effective pollinators? Ecology Letters 17, 388-400, doi: 10.1111/ele.12224.

Sutrisno H. 2008. Moth diversity at Gunung Halimun-Salak National Park, West Java. HAYATI Journal of Biosciences 15, 111-117, doi: 10.4308/hjb.15.3.111.

Taylor R.H. 1971. Influence of man on vegetation and wildlife of Enderby and Rose Islands, Auckland Islands. New Zealand Journal of Botany 9, 225-268, doi: 10.1080/ 0028825X.1971.10429139.

Thomas J.A., Telfer M.G., Roy D.B., Preston C.D., Greenwood J.J.D., Asher J., Fox R., Clarke R.T. \& Lawton J.H. 2004. Comparative losses of British butterflies, birds, and plants and the global extinction crisis. Science 303, 1879-1881, doi: 10.1126/science.1095046.

Thomson G.M. 1928. The pollination of New Zealand flowers by birds and insects. Transactions and Proceedings of the New Zealand Institute 57, 106-125.

Wood J.R., Wilmshurst J.M., Turney C.S.M. \& Fogwill C.J. 2016. Palaeoecological signatures of vegetation change induced by herbivory regime shifts on Subantarctic Enderby Island. Quaternary Science Reviews 134, 51-58, doi: 10.1016/j.quascirev.2015.12.018. 